\section{Los conservadores bonaerenses: un partido desde el gobierno}

María Dolores Béjar
María Dolores Béjar es Profesora de la Facultad

de Humanidades y Ciencias de la Educación, Universidad

Nacional de La Plata, calle 48, entre 6 y 7, piso 5, (1900)

La Plata. Tel. 0221-4229130.

E-mail: doloresmaria@sinectis.com.ar

\section{Resumen}

En este trabajo se revisan las prácticas electorales distintivas del orden conservador en la provincia de Buenos Aires con el objetivo de precisar la fisonomía de uno de los principales protagonistas del régimen fraudulento: Ios conservadores bonaerenses. En la primera parte, a través del registro de los debates en el Congreso entre 1912 y 1916, se contrasta la significación asignada a la figura del gobierno elector por los dirigentes de la oposición, con la versión crítica, pero de signo contrario, de un sector de la dirigencia conservadora. En el cuerpo central del artículo, se reconstruyen las prácticas y las propuestas de las fuerzas conservadoras a la luz de las controversias en torno a la reforma de la legislación electoral de la provincia entre 1910 y 1913. A través de este debate, los conservadores bonaerenses se presentan como un actor escasamente cohesionado y atravesado por dos fuerzas en tensión: la que expresaba el interés de los jefes políticos por preservar la autonomía de los gobiernos locales y la que proponía el disciplinamiento de los mismos, a través del fortalecimiento del gobierno central.

\section{Summary}

In this work we are going to review the electoral practice that distinct the conservative order in province of Buenos Aires (Argentina) with the object of specifing the physiognomy of one of the principal protagonist from the fraudulent regime: the "conservadores" from Buenos Aires province. In the first part, through the debate's register in the Congress between 1912 and 1916, we can contrast the signification assigned to the figure of the elector government by the opponent leaders, with the critical version, but of opposite sign, from one sector of the conservative party leaders. In the article's main part, we reconstruct practices and proposals from the conservative forces, in connecting with the controversies around the electoral legislation's reform controversy in the province between 1910 and 1913. Through this debate, the "conservadores" from Buenos Aires present themselves as a political actor scarcely cohesive and lying across two forces in tension. One of the forces expressed the political leader interest to preserve the autonomy of the local governments, and the other proposed to discipline them through the central government's invigoration. 